Check for updates

Cite this: RSC Adv., 2018, 8, 4695

Received 25th December 2017 Accepted 18th January 2018

DOI: $10.1039 / c 7 r a 13629 c$

rsc.li/rsc-advances

\section{Acid-base sites synergistic catalysis over Mg-Zr-Al mixed metal oxide toward synthesis of diethyl carbonate $\uparrow$}

\author{
Tingting Yan, Weihan Bing, Ming Xu, Yinwen Li, Yusen Yang, Guoqing Cui, \\ Lan Yang (D)* and Min Wei (D) *
}

In heterogeneous catalysis processes, development of high-performance acid-base sites synergistic catalysis has drawn increasing attention. In this work, we prepared $\mathrm{Mg} / \mathrm{Zr} / \mathrm{Al}$ mixed metal oxides (denoted as $\mathrm{Mg}_{2} \mathrm{Zr}_{x} \mathrm{Al}_{1-x}-\mathrm{MMO}$ ) derived from $\mathrm{Mg}-\mathrm{Zr}-\mathrm{Al}$ layered double hydroxides (LDHs) precursors. Their catalytic performance toward the synthesis of diethyl carbonate (DEC) from urea and ethanol was studied in detail, and the highest catalytic activity was obtained over the $\mathrm{Mg}_{2} \mathrm{Zr}_{0.53} \mathrm{Al}_{0.47} \mathrm{MMO}$ catalyst (DEC yield: $37.6 \%$ ). By establishing correlation between the catalytic performance and Lewis acid-base sites measured by $\mathrm{NH}_{3}-\mathrm{TPD}$ and $\mathrm{CO}_{2}-\mathrm{TPD}$, it is found that both weak acid site and medium strength base site contribute to the overall yield of DEC, which demonstrates an acid-base synergistic catalysis in this reaction. In addition, in situ Fourier transform infrared spectroscopy (in situ FTIR) measurements reveal that the Lewis base site activates ethanol to give ethoxide species; while Lewis acid site facilitates the activated adsorption of urea and the intermediate ethyl carbamate (EC). Therefore, this work provides an effective method for the preparation of tunable acid-base catalysts based on LDHs precursor approach, which can be potentially used in cooperative acid-base catalysis reaction.

\section{Introduction}

Dialkyl carbonates have attracted widespread interest during the last decades due to their extensive industrial applications. ${ }^{1}$ As an important homologue of the dialkyl carbonate family, diethyl carbonate (DEC) has become increasingly important as a green solvent, a replacement of some toxic substances such as phosgene, dimethyl sulphate and alkyl halide in carbonylation and alkylation reactions, and an electrolyte in lithium ion batteries. ${ }^{2-4}$ Additionally, DEC can be used as an ideal additive for gasoline for its higher oxygen content and favorable fuel/ water distribution coefficient with negligible environmental pollution. ${ }^{5}$ Up to now, DEC can be synthetized via several routes: phosgenation of ethanol, ${ }^{6}$ oxidative carbonylation of ethanol, ${ }^{7,8}$ transesterification of organic carbonates, ${ }^{\mathbf{9 , 1 0}}$ and ethanolysis of urea, ${ }^{\mathbf{1 1}, \mathbf{1 2}}$ among which ethanolysis of urea is particularly promising due to cost effectiveness, mild reaction conditions and safe operations. Furthermore, this process involves an indirect utilization of $\mathrm{CO}_{2}$ : the by-product ammonia can be recycled and further reacts with $\mathrm{CO}_{2}$ to produce urea,

State Key Laboratory of Chemical Resource Engineering, Beijing Advanced Innovation Center for Soft Matter Science and Engineering, Beijing University of Chemical Technology, Beijing 100029, P. R. China. E-mail: yanglan@mail.buct.edu.cn; weimin@mail.buct.edu.cn

$\dagger$ Electronic supplementary information (ESI) available. See DOI: $10.1039 / \mathrm{c} 7 \mathrm{ra13629c}$ which is sustainable and friendly process. Zinc oxide (ZnO) catalyst has been commonly used in this reaction with a relatively high yield of DEC, but suffered from dissolution of solid ZnO during the reaction. ${ }^{13}$ Therefore, the exploration of highly efficient, stable catalysts is desirable. Previous studies have shown that both acidity and basicity are crucial to determine the catalytic performance in ethanolysis of urea $;^{\mathbf{1 4 , 1 5}}$ however, the cooperation of acid-base sites as well as their respective contribution to catalytic performance are unclear. Thus, how to tune the acid-base properties of catalysts so as to achieve a synergistic catalysis with a high stability and efficiency remains a challenge.

Layered double hydroxides (LDHs) ${ }^{\mathbf{1 6}, 17}$ are a class of anionic clay materials with alternating cationic brucite-type layers and charge-balancing anions located in the interlayer region, which can be represented by the formula $\left[\mathrm{M}_{1-x}{ }^{2+} \mathrm{M}_{x}{ }^{3+}(\mathrm{OH})_{2}\right]\left(\mathrm{A}^{n-}\right)_{x / n} \cdot m \mathrm{H}_{2} \mathrm{O}$. In recent years, LDHs materials have attracted an intensive attention as catalysts and catalyst supports in heterogeneous catalysis, owing to their tunability in chemical composition and phase transformation from metal hydroxides to mixed metal oxides (MMOs) upon calcination treatments. ${ }^{18}$ If the chemical composition and element ratio in LDHs host matrix are modulated, the resulting MMOs would possess versatility in concentration and intensity of Lewis acid-base sites. This inspires us to explore the synthesis of $\mathrm{LDH}$ precursors and precise control over their 
structural transformation process, for the purpose of attaining acid-base sites synergistic catalysis toward synthesis of DEC.

In this work, $\mathrm{Mg} / \mathrm{Zr} / \mathrm{Al}$ mixed metal oxides (denoted as $\mathrm{Mg}_{2} \mathrm{Zr}_{x} \mathrm{Al}_{1-x}-\mathrm{MMO}$ ) were prepared by a facile phase transformation process from $\mathrm{Mg}_{2} \mathrm{Zr}_{x} \mathrm{Al}_{1-x}-\mathrm{LDH}$ precursors, and their catalytic performance toward DEC synthesis from urea and ethanol was investigated. A tunable acid-base site can be obtained via changing the $\mathrm{Zr} / \mathrm{Al}$ molar ratio in the LDHs precursors. The $\mathrm{Mg}_{2} \mathrm{Zr}_{0.53} \mathrm{Al}_{0.47} \mathrm{MMO}$ catalyst demonstrates the best catalytic behavior with a DEC yield of $37.6 \%$, which is among the highest level compared with previous studies. It is found that the synergistic catalysis between weak Lewis acid and medium strength Lewis base site is responsible for the DEC production: medium strength base site facilitates the activated adsorption of ethanol while weak acid site activates urea and intermediate ethyl carbamate (EC, the intermediate production from the reaction of ethanol and urea), which is revealed by in situ FTIR measurements.

\section{Experiment section}

\subsection{Materials}

Chemical reagents, including $\mathrm{Mg}\left(\mathrm{NO}_{3}\right)_{2} \cdot 6 \mathrm{H}_{2} \mathrm{O}, \mathrm{ZrO}\left(\mathrm{NO}_{3}\right)_{2}$ $\cdot x \mathrm{H}_{2} \mathrm{O}, \mathrm{Al}\left(\mathrm{NO}_{3}\right)_{3} \cdot 9 \mathrm{H}_{2} \mathrm{O}, \mathrm{NaOH}, \mathrm{Na}_{2} \mathrm{CO}_{3}$, ethanol, urea, and cyclohexanol was purchased and used without further purification. Deionized water was used in all the experimental processes.

\subsection{Synthesis of MgZrAl-LDH precursors and MgZrAl-MMO catalysts}

MgZrAl-LDH precursors with various compositions were synthesized by a co-precipitation method. Typically, $\mathrm{Mg}\left(\mathrm{NO}_{3}\right)_{2}$ $\cdot 6 \mathrm{H}_{2} \mathrm{O}, \mathrm{ZrO}\left(\mathrm{NO}_{3}\right)_{2} \cdot x \mathrm{H}_{2} \mathrm{O}$ and $\mathrm{Al}\left(\mathrm{NO}_{3}\right)_{3} \cdot 9 \mathrm{H}_{2} \mathrm{O}$ with $\mathrm{Mg}^{2+} /\left(\mathrm{Zr}^{4+}+\right.$ $\mathrm{Al}^{3+}$ ) molar ratio of 2 were dissolved in $200 \mathrm{~mL}$ of deionized water to give a solution with a total cationic concentration of $0.1 \mathrm{M}$ (solution A). $\mathrm{NaOH}(2 \mathrm{M})$ and $\mathrm{Na}_{2} \mathrm{CO}_{3}(0.3 \mathrm{M})$ were dissolved in water $(100 \mathrm{~mL})$ to obtain a base solution (solution $\mathrm{B}$ ). Solution B was added dropwise to solution A at $45{ }^{\circ} \mathrm{C}$ with vigorous stirring until the $\mathrm{pH}$ value of the slurry reached to 10 . The slurry was aged at $75{ }^{\circ} \mathrm{C}$ for $12 \mathrm{~h}$, and the obtained precipitate was washed thoroughly and dried in an oven at $60^{\circ} \mathrm{C}$ overnight. The resulting sample is labeled as $\mathrm{Mg}_{2} \mathrm{Zr}_{x} \mathrm{Al}_{1-x}-\mathrm{LDH}$, where $x$ is the molar ratio of $\mathrm{Zr} /(\mathrm{Zr}+\mathrm{Al})$. Subsequently, the $\mathrm{Mg}_{2} \mathrm{Zr}_{x} \mathrm{Al}_{1-x}-\mathrm{LDH}$ precursor was calcined at $550{ }^{\circ} \mathrm{C}$ for $4 \mathrm{~h}$ in a $\mathrm{N}_{2}$ atmosphere at a heating rate of $5{ }^{\circ} \mathrm{C} \min ^{-1}$. The calcination process results in the phase transformation from $\mathrm{Mg}_{2} \mathrm{Zr}_{x} \mathrm{Al}_{1-x^{-}}$ $\mathrm{LDH}$ precursor to $\mathrm{MgO}-\mathrm{ZrO}_{2}-\mathrm{Al}_{2} \mathrm{O}_{3}$ mixed metal oxides (denoted as $\left.\mathrm{Mg}_{2} \mathrm{Zr}_{x} \mathrm{Al}_{1-x}-\mathrm{MMO}\right)$.

\subsection{Catalytic evaluation}

The catalytic performance was conducted on a stainless steel autoclave $(50 \mathrm{~mL})$ equipped with a magnetic stirrer. In a typical method, the catalyst, urea, and ethanol were packed into the reaction reactor. The air in the reaction reactor was replaced by $\mathrm{N}_{2}$ three times and then sealed. The reaction was performed at $200{ }^{\circ} \mathrm{C}$ for $5 \mathrm{~h}$. The product was analyzed off-line by using gas chromatograph (Shimadzu GC-2014C equipped with a flame ionization detector). The internal standard method was applied for the quantitative analysis with cyclohexanol as internal standard. For recycling tests, the used catalyst was separated from the liquid by centrifugation, washed thoroughly and dried, and then reused for the next reaction cycle.

For the reaction of urea and ethanol, the yield of diethyl carbonate (DEC) or ethyl carbamate (EC) was determined by the formulas:

$$
Y=\frac{M}{\text { starting urea }(\mathrm{mol})} \times 100 \%
$$

where $M$ represents the cumulative mole number of DEC or EC, respectively.

\subsection{Characterization}

Transmission electron microscopy (TEM) and high-resolution TEM (HRTEM) observations were carried out on a JEOL JEM2100 transmission electron microscope. The morphology of the samples was investigated using a Zeiss Supra 55 scanning electron microscope (SEM) with an accelerating voltage of $20 \mathrm{kV}$. Powder X-ray diffraction (XRD) patterns were obtained on a Rigaku XRD-6000 diffractometer, using $\mathrm{Cu} \mathrm{K} \alpha$ radiation $(\lambda=$ $0.15418 \mathrm{~nm}$ ) at $40 \mathrm{kV}, 30 \mathrm{~mA}$, a scanning rate of $10^{\circ} \mathrm{min}^{-1}$, and a $2 \theta$ angle ranging from 3 to $90^{\circ}$. Low-temperature $\mathrm{N}_{2}$ adsorption-desorption isotherms of the samples were obtained on a Quantachrome Autosorb-1C-VP analyzer. Prior to $\mathrm{N}_{2}$ adsorption, the sample was outgassed at $200{ }^{\circ} \mathrm{C}$ overnight. The total specific surface area was evaluated from the multipoint Brunauer-Emmett-Teller (BET) method.

In situ Fourier-transformed infrared absorption of pyridine (Py-IR) spectra were obtained using a Nicolet 380 instrument spectrophotometer. The sample $(20 \mathrm{mg})$ was pressed into a selfsupporting wafer and installed in an IR cell with $\mathrm{CaF}_{2}$ window, activated at $450{ }^{\circ} \mathrm{C}$ for $1 \mathrm{~h}$ in a flow of $\mathrm{N}_{2}$, and then the temperature was cooled down to $150{ }^{\circ} \mathrm{C}$ for recording the background spectrum. Subsequently, pyridine was introduced into the cell at $150{ }^{\circ} \mathrm{C}$ for $1 \mathrm{~h}$. The spectra were recorded after the sample was purged with flowing $\mathrm{N}_{2}$ to remove physisorbed pyridine.

Temperature-programmed desorption (TPD) was performed by using a Micromeritics AutoChem II 2920 apparatus, equipped with a thermal conductivity detector (TCD). Prior to adsorption, the sample $(100 \mathrm{mg})$ was pretreated in a helium flow $\left(50 \mathrm{~cm}^{3} \mathrm{~min}^{-1}\right)$ at $823 \mathrm{~K}$ for $1 \mathrm{~h}$ (heating rate: $10{ }^{\circ} \mathrm{C} \mathrm{min}^{-1}$ ) and then cooled to $50{ }^{\circ} \mathrm{C}$. The sample was exposed to $\mathrm{CO}_{2}$ or $\mathrm{NH}_{3}$ for $0.5 \mathrm{~h}$, and then was maintained in a He flow for $1 \mathrm{~h}$ to remove physisorbed $\mathrm{CO}_{2}$ or $\mathrm{NH}_{3}$. Afterwards, the temperature was increased linearly at a rate of $10{ }^{\circ} \mathrm{C} \min ^{-1}$ to $600{ }^{\circ} \mathrm{C}$ for recording the signal of $\mathrm{CO}_{2}$ or $\mathrm{NH}_{3}$.

In situ Fourier transform infrared spectroscopy (in situ FTIR) measurements were carried out using a Nicolet 380 instrument spectrophotometer with $4 \mathrm{~cm}^{-1}$ of resolution. For the adsorption study of urea (or EC), $2 \mathrm{mg}$ of urea (or EC) and $20 \mathrm{mg}$ of catalyst were pressed into a self-supporting wafer, and then was packed into the IR cell. In the case of ethanol adsorption, the 
catalyst $(20 \mathrm{mg})$ was pressed into a self-supporting wafer and installed in the IR cell, followed by the introduction of ethanol vapor. IR spectra were recorded in the temperature range 30$210{ }^{\circ} \mathrm{C}$.

\section{Results and discussion}

\subsection{Structural and morphological studies on catalysts}

Fig. 1A shows the XRD patterns of as-synthesized $\mathrm{Mg}_{2} \mathrm{Zr}_{x} \mathrm{Al}_{1-x^{-}}$ $\mathrm{LDH}$ precursors with various $\mathrm{Mg} / \mathrm{Zr} / \mathrm{Al}$ molar ratios. All the samples exhibit characteristic Bragg reflections at $2 \theta 12^{\circ}$ and $24^{\circ}$, which can be indexed to (003) and (006) of an LDH structure (JCPDS no. 35-0964), respectively. However, the crystallinity of $\mathrm{Mg}_{2} \mathrm{Zr}_{x} \mathrm{Al}_{1-x}-\mathrm{LDH}$ decreases gradually with the increase of $\mathrm{Zr}$ content, probably owing to the distortion in $\mathrm{LDH}$ layers caused by the substitution of $\mathrm{Al}^{3+}$ (ionic radius $0.053 \mathrm{~nm}$ ) by $\mathrm{Zr}^{4+}$ (ionic radius $0.072 \mathrm{~nm}$ ). Calcination of $\mathrm{LDH}$ precursors at $550{ }^{\circ} \mathrm{C}$ results in the structural transformation from LDHs to mixed metal oxides. XRD patterns of $\mathrm{Mg}_{2} \mathrm{Zr}_{x} \mathrm{Al}_{1-x}-\mathrm{MMO}$ samples (Fig. 1B) give superimposition of two kinds of oxide phases: Bragg reflections at $2 \theta 36^{\circ}, 43^{\circ}$ and $63^{\circ}$ are indexed to (111), (200) and (220) of periclase $\mathrm{MgO}$ phase (JCPDS no. 45-0946) and those at $2 \theta 30^{\circ}$ and $51^{\circ}$ indicate the existence of tetragonal $\mathrm{ZrO}_{2}$
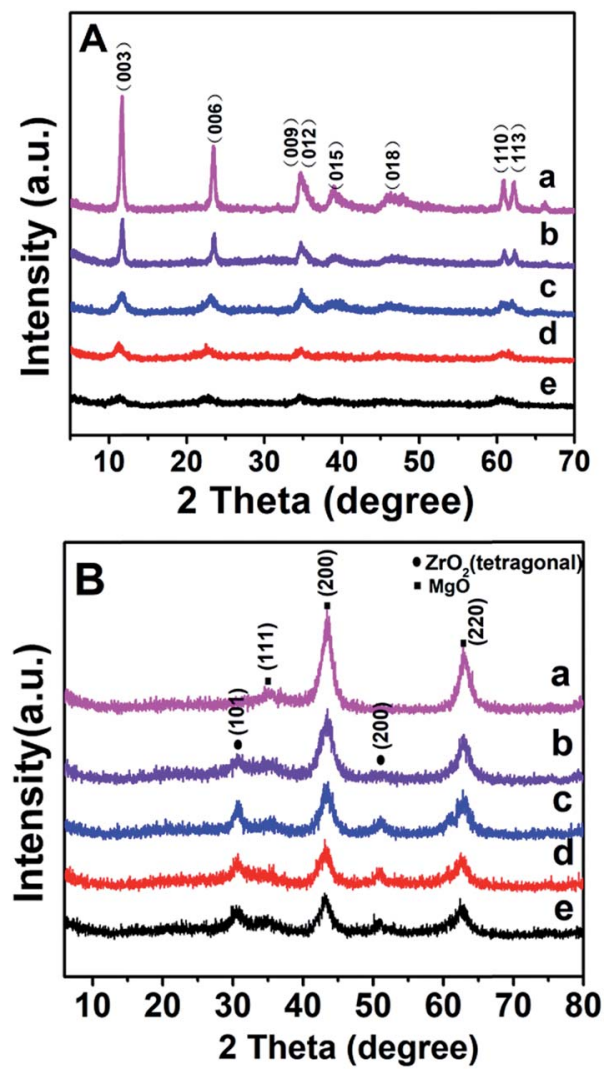

Fig. 1 (A) XRD patterns of LDH precursors: (a) $\mathrm{Mg}_{2} \mathrm{Al}-\mathrm{LDH}$, (b) $\mathrm{Mg}_{2}-$ $\mathrm{Zr}_{0.22} \mathrm{Al}_{0.78}-\mathrm{LDH}$ ，(c) $\mathrm{Mg}_{2} \mathrm{Zr}_{0.33} \mathrm{Al}_{0.67}-\mathrm{LDH}$ ，(d) $\mathrm{Mg}_{2} \mathrm{Zr}_{0.53} \mathrm{Al}_{0.47}-\mathrm{LDH}$, and (e) $\mathrm{Mg}_{2} \mathrm{Zr}_{0.67} \mathrm{Al}_{0.33}-\mathrm{LDH}$. (B) $X R D$ patterns of (a) $\mathrm{Mg}_{2} \mathrm{Al}-\mathrm{MMO}$, (b) $\mathrm{Mg}_{2} \mathrm{Zr}_{0.22} \mathrm{Al}_{0.78}-\mathrm{MMO}$, (c) $\mathrm{Mg}_{2} \mathrm{Zr}_{0.33} \mathrm{Al}_{0.67}-\mathrm{MMO}$, (d) $\mathrm{Mg}_{2} \mathrm{Zr}_{0.53} \mathrm{Al}_{0.47}-$ $\mathrm{MMO}$, and (e) $\mathrm{Mg}_{2} \mathrm{Zr}_{0.67} \mathrm{Al}_{0.33}-\mathrm{MMO}$. Crystalline phase: (O) $\mathrm{ZrO}_{2}$, ( $\mathrm{MgO}$.
$\left(\mathrm{t}-\mathrm{ZrO}_{2}\right)$ phase (JCPDS no. 42-1164). Interestingly, with the increase of $\mathrm{Zr} / \mathrm{Mg}$ molar ratio, the peak intensity of $\mathrm{MgO}$ phase decreases gradually while that of $\mathrm{ZrO}_{2}$ phase enhances progressively. Additionally, no reflection of $\mathrm{Al}_{2} \mathrm{O}_{3}$ is observed, indicating an amorphous phase.

As a typical sample, the structural transformation from $\mathrm{Mg}_{2} \mathrm{Zr}_{0.53} \mathrm{Al}_{0.47}-\mathrm{LDH}$ precursor to $\mathrm{Mg}_{2} \mathrm{Zr}_{0.53} \mathrm{Al}_{0.47}-\mathrm{MMO}$ was studied by SEM, TEM and HRTEM measurements (Fig. 2). The $\mathrm{Mg}_{2} \mathrm{Zr}_{0.53} \mathrm{Al}_{0.47}-\mathrm{LDH}$ precursor (Fig. 2A and $\mathrm{C}$ ) shows smooth and uniform thin platelet nanocrystal; $\mathrm{Mg}_{2} \mathrm{Zr}_{0.53} \mathrm{Al}_{0.47}-\mathrm{MMO}$ still inherits the original lamellar morphology of LDH precursor (Fig. 2B and D), but with a porous structure resulting from the calcination process. In addition, HRTEM image of $\mathrm{Mg}_{2} \mathrm{Zr}_{0.53}$ $\mathrm{Al}_{0.47}-\mathrm{MMO}$ sample (Fig. 2E) exhibits two identified lattice fringe distances of $0.210 \mathrm{~nm}$ and $0.295 \mathrm{~nm}$, which are indexed to the (200) plane of $\mathrm{MgO}$ and (101) plane of $\mathrm{t}-\mathrm{ZrO}_{2}$ phase, respectively. This displays a homogeneous dispersion of $\mathrm{MgO}$ and $\mathrm{t}-\mathrm{ZrO}_{2}$ in an amorphous $\mathrm{Al}_{2} \mathrm{O}_{3}$ platelet matrix, in good accordance with the XRD results.

Specific surface area and pore-size distribution of all these $\mathrm{Mg}_{2} \mathrm{Zr}_{x} \mathrm{Al}_{1-x}-\mathrm{MMO}$ samples were studied by the nitrogen adsorption-desorption isotherms and porosity measurements. All the samples display IV type isotherms with H3 shaped hysteresis loops, which are typical characteristic of mesoporous materials and plate-like particles (Fig. 3). As listed in Table 1, with the increase of $\mathrm{Zr}$ content, the surface area shows an increase trend from $113.27 \mathrm{~m}^{2} \mathrm{~g}^{-1}$ to $159.45 \mathrm{~m}^{2} \mathrm{~g}^{-1}$ and then decreases to $143.64 \mathrm{~m}^{2} \mathrm{~g}^{-1}$, with an average pore diameter ranging in 8-10 $\mathrm{nm}$. Noticeably, in comparison with the $\mathrm{Mg}_{2} \mathrm{Al}-$ MMO sample (111.12 $\mathrm{m}^{2} \mathrm{~g}^{-1}$ ), the $\mathrm{Mg}_{2} \mathrm{Zr}_{x} \mathrm{Al}_{1-x}-$ MMO samples show higher surface area (113.27-159.45 $\mathrm{m}^{2} \mathrm{~g}^{-1}$ ), as a result of the introduction of $\mathrm{Zr}$, which would be favorable in heterogeneous catalysis process.

\subsection{Acid-base properties of catalysts}

$\mathrm{CO}_{2}$-TPD, $\mathrm{NH}_{3}$-TPD and IR spectroscopy of adsorbed pyridine (Py-IR) are powerful measurements to investigate the concentration and strength of basic and acid sites of catalyst, ${ }^{19}$ which were performed in this work (Fig. 4 and Table 2). For the $\mathrm{CO}_{2}$ TPD profiles, the samples show a broad $\mathrm{CO}_{2}$ desorption peak in the range $50-550{ }^{\circ} \mathrm{C}$, which can be deconvoluted into three peaks with maximal temperatures $\left(T_{\mathrm{M}}\right)$ in the region 120$130{ }^{\circ} \mathrm{C}, 170-220{ }^{\circ} \mathrm{C}, 300-350{ }^{\circ} \mathrm{C}$ by a Gaussian peak fitting method, corresponding to the weak, medium and strong base site, respectively. According to previous studies, the weak, medium and strong base site are derived from $\mathrm{OH}$ group, metal-oxygen pair and low-coordination oxygen anion, respectively. ${ }^{20}$ In the case of $\mathrm{NH}_{3}$-TPD profiles, three desorption peaks with $T_{\mathrm{M}}$ at $\sim 130{ }^{\circ} \mathrm{C}, 250{ }^{\circ} \mathrm{C}$ and $350{ }^{\circ} \mathrm{C}$ are denoted as the weak, medium and strong acid site, respectively. ${ }^{21,22}$ Notably, it is observed that with the increase of $\mathrm{Zr}^{4+} /\left(\mathrm{Zr}^{4+}+\mathrm{Al}^{3+}\right)$ ratio from 0.22 to 0.53 , the amount of medium basic site or weak acid site enhances significantly, and then decreases from 0.53 to 0.67 . The sample of $\mathrm{Mg}_{2} \mathrm{Zr}_{0.53} \mathrm{Al}_{0.47}-\mathrm{MMO}$ gives the largest amount of both medium basic site and weak acid site, showing a $\mathrm{Zr}^{4+} / \mathrm{Al}^{3+}$ ratio-dependent acid-base site. The increment of medium basic 

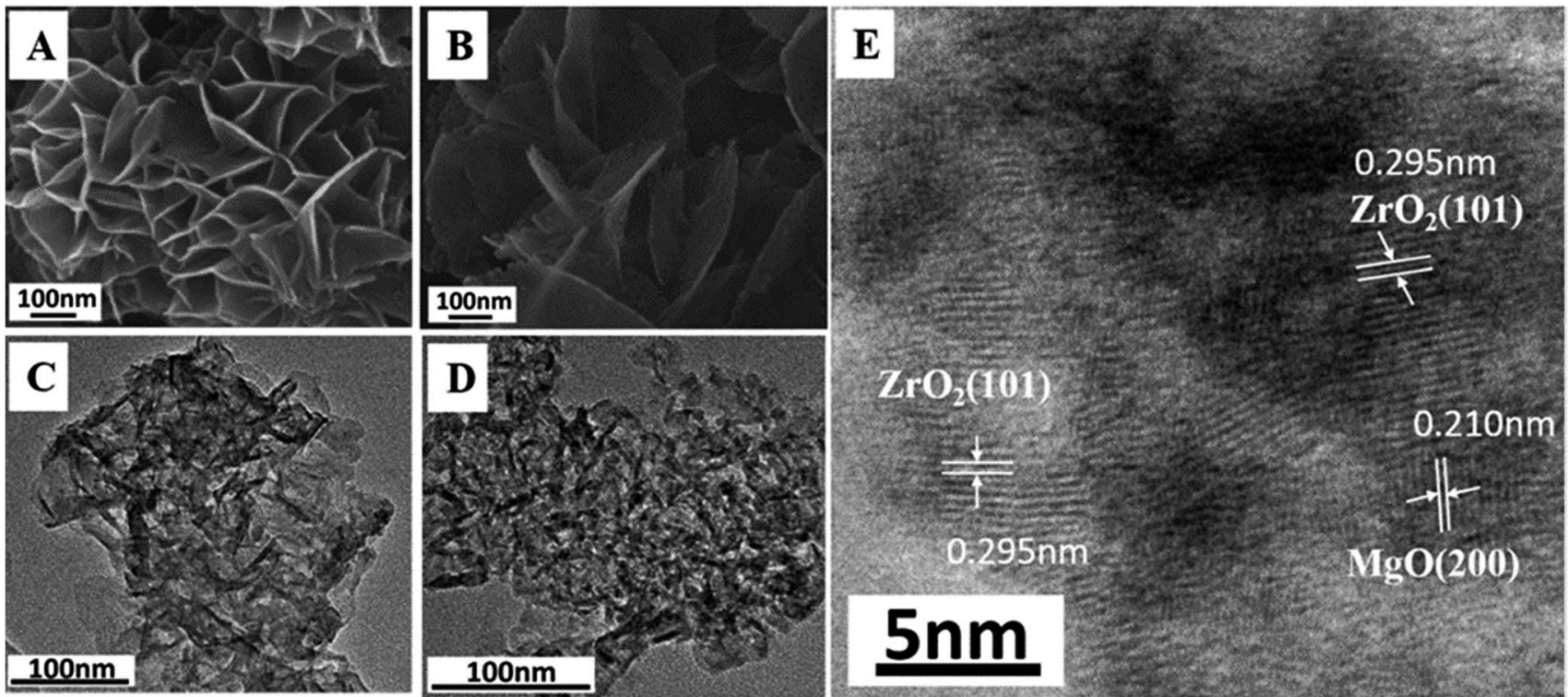

Fig. 2 SEM images of (A) Mg $Z_{2} r_{0.53} A_{0.47}-L D H,(B) M g_{2} Z_{0.53} A l_{0.47}-M M O$. TEM images of (C) $M_{2} Z_{2} r_{0.53} A_{0.47}-L D H$, (D) Mg $Z_{2} r_{0.53} A l_{0.47}-M M O$. (E) HRTEM image of $\mathrm{Mg}_{2} \mathrm{Zr}_{0.53} \mathrm{Al}_{0.47}-\mathrm{MMO}$.
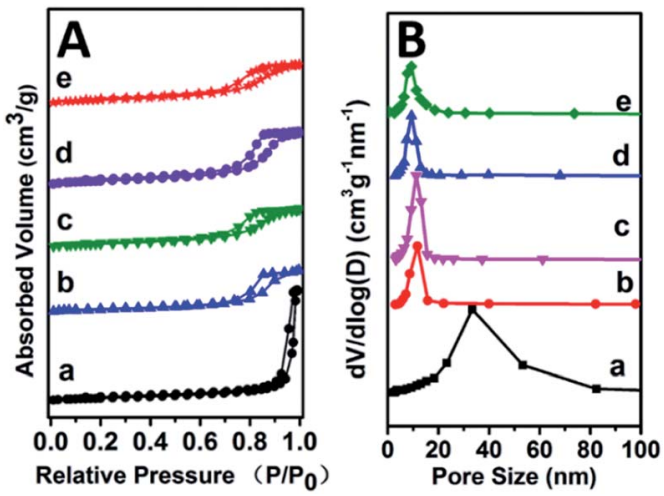

Fig. 3 (A) $\mathrm{N}_{2}$ adsorption-desorption curves and (B) pore size distributions of: (a) $\mathrm{Mg}_{2} \mathrm{Al}-\mathrm{MMO}$, (b) $\mathrm{Mg}_{2} \mathrm{Zr}_{0.22} \mathrm{Al}_{0.78}-\mathrm{MMO}$, (c) $\mathrm{Mg}_{2} \mathrm{Zr}_{0.33^{-}}$ $\mathrm{Al}_{0.67}-\mathrm{MMO}$, (d) $\mathrm{Mg}_{2} \mathrm{Zr}_{0.53} \mathrm{Al}_{0.47}-\mathrm{MMO}$, (e) $\mathrm{Mg}_{2} \mathrm{Zr}_{0.67} \mathrm{Al}_{0.33}-\mathrm{MMO}$.

Table 1 Structural parameters of various samples

\begin{tabular}{llcl}
\hline Sample & $S_{\mathrm{BET}}{ }^{a} / \mathrm{m}^{2} \mathrm{~g}^{-1}$ & $D_{\mathrm{BJH}}{ }^{b} / \mathrm{nm}$ & $V_{\mathrm{BJH}}{ }^{c} / \mathrm{cm}^{3} \mathrm{~g}^{-1}$ \\
\hline $\mathrm{Mg}_{2} \mathrm{Al}-\mathrm{MMO}$ & 111.12 & 30.87 & 1.11 \\
$\mathrm{Mg}_{2} \mathrm{Zr}_{0.22} \mathrm{Al}_{0.78}-\mathrm{MMO}$ & 113.27 & 10.28 & 0.41 \\
$\mathrm{Mg}_{2} \mathrm{Zr}_{0.33} \mathrm{Al}_{0.67}-\mathrm{MMO}$ & 129.16 & 9.78 & 0.57 \\
$\mathrm{Mg}_{2} \mathrm{Zr}_{0.53} \mathrm{Al}_{0.47}-\mathrm{MMO}$ & 159.45 & 8.32 & 0.43 \\
$\mathrm{Mg}_{2} \mathrm{Zr}_{0.67} \mathrm{Al}_{0.33}-\mathrm{MMO}$ & 143.64 & 8.21 & 0.42
\end{tabular}

${ }^{a}$ BET surface area. ${ }^{b} \mathrm{BJH}$ desorption average pore diameter. ${ }^{c} \mathrm{BJH}$ desorption cumulative pore volume.

site can be attributed to the enrichment of $\mathrm{Zr}^{4+}-\mathrm{O}^{2-}$, in light of a constant $\mathrm{Mg}$ content $\left(\mathrm{Mg}^{2+}-\mathrm{O}^{2-}\right)$ in all these samples. As for the increase of weak acid site, we propose that $\mathrm{ZrO}_{2}$ phase gives predominant contribution, since $\mathrm{Al}_{2} \mathrm{O}_{3}$ mainly provides medium-strong acid site. ${ }^{23-25}$ It should be noted that the sample of $\mathrm{Mg}_{2} \mathrm{Zr}_{0.53} \mathrm{Al}_{0.47}-\mathrm{MMO}$ possesses the largest specific surface area $\left(159.45 \mathrm{~m}^{2} \mathrm{~g}^{-1}\right)$, which is favorable for the exposure of medium basic or weak acid site. In addition, Py-IR measurements were performed over $\mathrm{Mg}_{2} \mathrm{Zr}_{x} \mathrm{Al}_{1-x}$-MMO samples to study Lewis and Brønsted acid site. ${ }^{26,27}$ All these samples display a characteristic band of pyridine adsorption at $1444 \mathrm{~cm}^{-1}$, indicating the presence of Lewis acid site originating from $\mathrm{ZrO}_{2}$ and $\mathrm{Al}_{2} \mathrm{O}_{3}$. Moreover, as the $\mathrm{Zr} / \mathrm{Al}$ ratio increases, the peak intensity at $1444 \mathrm{~cm}^{-1}$ strengthens gradually and reaches to maximum value over the sample of $\mathrm{Mg}_{2} \mathrm{Zr}_{0.53} \mathrm{Al}_{0.47}-\mathrm{MMO}$, consistent with the results of $\mathrm{NH}_{3}$-TPD.

\subsection{Catalytic performance of catalysts}

The catalytic performance of $\mathrm{Mg}_{2} \mathrm{Zr}_{x} \mathrm{Al}_{1-x}-\mathrm{MMO}$ catalysts toward the synthesis of DEC from ethanol and urea was studied. As shown in Fig. 5A, the yield of DEC shows an increase trend (from $19.9 \%$ to $37.6 \%$ ) as the reaction temperature rises from 180 to $200{ }^{\circ} \mathrm{C}$, followed by a decrease (from $37.6 \%$ to $33.0 \%$ ) within $200-210^{\circ} \mathrm{C}$. In contrast, the intermediate product, ethyl carbamate (EC), shows an opposite change tendency, with the lowest yield at $200{ }^{\circ} \mathrm{C}$. The reason is that a higher reaction temperature will lead to the reverse reaction from DEC to EC as well as the decomposition of EC to $N$-ethyl ethyl carbamate (side reactions). ${ }^{14}$ Thus, the reaction temperature is chosen as $200{ }^{\circ} \mathrm{C}$. Fig. 5B displays the DEC synthesis as a function of reaction time, from which the largest yield of DEC is obtained at $5 \mathrm{~h}$. Afterwards, the influence of catalyst weight on the catalytic behavior was also studied, and it was found that DEC yield reached the maximal value at $10 \%$ catalyst weight (Fig. 5C). Finally, as for the urea/ethanol molar ratio (Fig. 5D), the yield of DEC achieves the largest one with the ethanol/urea molar ratio of 15.

Furthermore, the catalytic performance of various $\mathrm{Mg}_{2} \mathrm{Zr}_{x^{-}}$ $\mathrm{Al}_{1-x}-\mathrm{MMO}$ catalysts were evaluated under the optimum 

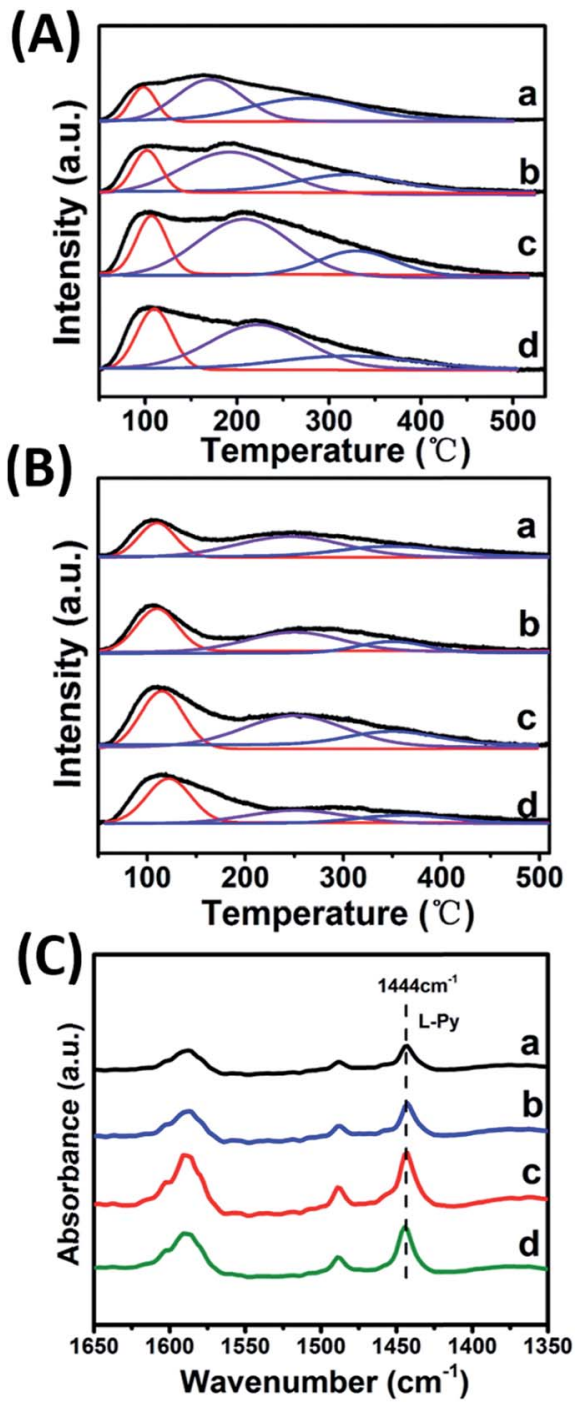

Fig. 4 (A) $\mathrm{CO}_{2}$-TPD, (B) $\mathrm{NH}_{3}-\mathrm{TPD}$ profiles and (C) Py-IR spectra of (a) $\mathrm{Mg}_{2} \mathrm{Zr}_{0.22} \mathrm{Al}_{0.78}-\mathrm{MMO}$, (b) $\mathrm{Mg}_{2} \mathrm{Zr}_{0.33} \mathrm{Al}_{0.67}-\mathrm{MMO}$, (c) $\mathrm{Mg}_{2} \mathrm{Zr}_{0.53} \mathrm{Al}_{0.47}-$ $\mathrm{MMO}$, and (d) $\mathrm{Mg}_{2} \mathrm{Zr}_{0.67} \mathrm{Al}_{0.33}-\mathrm{MMO}$.

catalytic reaction (Fig. $5 \mathrm{E}$ and Table 3 ). The $\mathrm{Mg}_{2} \mathrm{Al}-\mathrm{MMO}$ catalyst shows catalytic activity toward DEC synthesis, yielding 21.5\% DEC. The introduction of element $\mathrm{Zr}$ results in a significant enhancement: the DEC yield increases gradually from
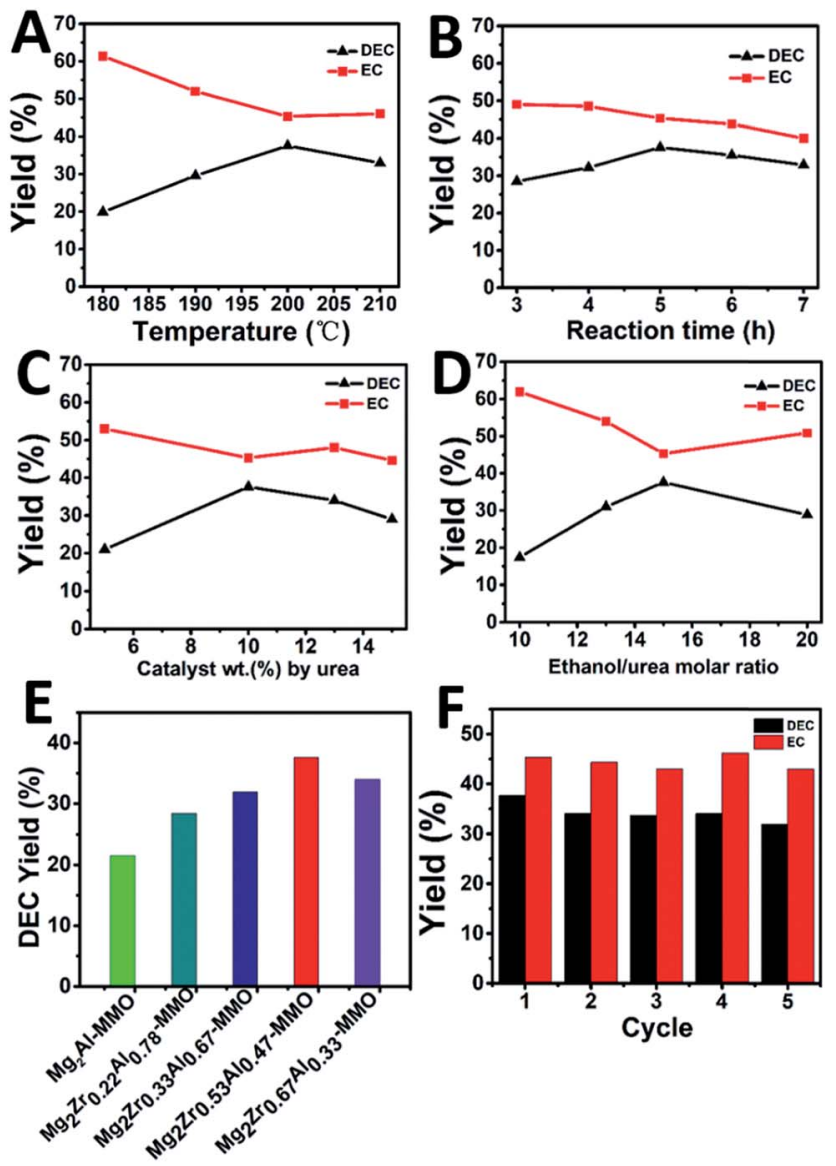

Fig. 5 Effects of reaction conditions on the yield of DEC over $\mathrm{Mg}_{2}$ $\mathrm{Zr}_{0.53} \mathrm{Al}_{0.47}-\mathrm{MMO}$ catalyst: (A) temperature, (B) reaction time, (C) the amount of catalyst and (D) ethanol/urea molar ratio as a function of DEC yield, respectively. (E) DEC yield over various catalysts under the following reaction conditions: $10 \mathrm{wt} \%$ catalyst (by urea), ethanol/urea molar ratio of $15, T=200{ }^{\circ} \mathrm{C}, t=5 \mathrm{~h}$. (F) Catalytic performances of $\mathrm{Mg}_{2} \mathrm{Zr}_{0.53} \mathrm{Al}_{0.47}-\mathrm{MMO}$ in 5 consecutive recycles.

$21.5 \%$ to $37.6 \%$ with the increase of $\mathrm{Zr}$ content, and then decreases to $34.0 \%$; the maximum value is present in the sample of $\mathrm{Mg}_{2} \mathrm{Zr}_{0.53} \mathrm{Al}_{0.47}-\mathrm{MMO}$. This is, to the best of our knowledge, among the highest level compared with previous reports..$^{6,11,12,14}$ In addition, the reusability of $\mathrm{Mg}_{2} \mathrm{Zr}_{0.53} \mathrm{Al}_{0.47^{-}}$ MMO catalyst was also studied (Fig. 5F). The used catalyst was

Table 2 Concentrations of base and acid site according to $\mathrm{CO}_{2}-\mathrm{TPD}$ and $\mathrm{NH}_{3}-\mathrm{TPD}$ profiles

\begin{tabular}{|c|c|c|c|c|c|c|c|c|}
\hline \multirow[b]{2}{*}{ Sample } & \multicolumn{4}{|c|}{ Base sites $\left(\mathrm{mmol} \mathrm{g}^{-1}\right)$} & \multicolumn{4}{|c|}{ Acid sites $\left(\mathrm{mmol} \mathrm{g}^{-1}\right)$} \\
\hline & $B_{\text {TOTAL }}{ }^{a}$ & $B_{\mathrm{W}}^{b}$ & $B_{\mathrm{M}}{ }^{b}$ & $B_{\mathrm{S}}{ }^{b}$ & $A_{\text {TOTAL }}{ }^{c}$ & $A_{\mathrm{W}}{ }^{d}$ & $A_{\mathrm{M}}{ }^{d}$ & $A_{\mathrm{S}}{ }^{d}$ \\
\hline $\mathrm{Mg}_{2} \mathrm{Zr}_{0.22} \mathrm{Al}_{0.78}-\mathrm{MMO}$ & 0.311 & 0.045 & 0.151 & 0.115 & 0.277 & 0.074 & 0.143 & 0.060 \\
\hline $\mathrm{Mg}_{2} \mathrm{Zr}_{0.33} \mathrm{Al}_{0.67}-\mathrm{MMO}$ & 0.367 & 0.060 & 0.209 & 0.098 & 0.299 & 0.115 & 0.132 & 0.052 \\
\hline $\mathrm{Mg}_{2} \mathrm{Zr}_{0.53} \mathrm{Al}_{0.47}-\mathrm{MMO}$ & 0.543 & 0.103 & 0.315 & 0.125 & 0.436 & 0.160 & 0.224 & 0.052 \\
\hline $\mathrm{Mg}_{2} \mathrm{Zr}_{0.67} \mathrm{Al}_{0.33}-\mathrm{MMO}$ & 0.411 & 0.076 & 0.254 & 0.081 & 0.306 & 0.143 & 0.107 & 0.056 \\
\hline
\end{tabular}

${ }^{a} B_{\text {TOTAL }}$ is the total concentration of base sites calculated based on $\mathrm{CO}_{2}$-TPD. ${ }^{b} B_{\mathrm{W}}, B_{\mathrm{M}}$, and $B_{\mathrm{S}}$ represent the concentration of weak, medium, and strong base site, respectively, which are calculated according to $\mathrm{CO}_{2}$-TPD and the deconvoluted TPD profiles in the temperature range $50-550{ }^{\circ} \mathrm{C}$. ${ }^{c} A_{\text {TOTAL }}$ is the total concentration of acid sites calculated based on $\mathrm{NH}_{3}$-TPD. ${ }^{d} A_{\mathrm{W}}, A_{\mathrm{M}}$, and $A_{\mathrm{S}}$ denote the concentration of weak, medium, and strong acid site, respectively, which are calculated according to $\mathrm{NH}_{3}$-TPD and the deconvoluted TPD profiles in the temperature range $50-550{ }^{\circ} \mathrm{C}$. 
Table 3 Catalytic performance of various catalysts

\begin{tabular}{lll}
\hline & \multicolumn{2}{l}{ Product yield (\%) } \\
\cline { 2 - 3 } Sample & EC & DEC \\
\hline $\mathrm{Mg}_{2} \mathrm{Al}-\mathrm{MMO}$ & 53.2 & 21.5 \\
$\mathrm{Mg}_{2} \mathrm{Zr}_{0.22} \mathrm{Al}_{0.78}-\mathrm{MMO}$ & 53.6 & 28.4 \\
$\mathrm{Mg}_{2} \mathrm{Zr}_{0.33} \mathrm{Al}_{0.67}-\mathrm{MMO}$ & 50.9 & 31.9 \\
$\mathrm{Mg}_{2} \mathrm{Zr}_{0.53} \mathrm{Al}_{0.47}-\mathrm{MMO}$ & 45.3 & 37.6 \\
$\mathrm{Mg}_{2} \mathrm{Zr}_{0.67} \mathrm{Al}_{0.33}-\mathrm{MMO}$ & 51.9 & 34.0 \\
\end{tabular}

separated from the liquid product by centrifugation, washed thoroughly and dried, directly reused for the next recycle evaluation. The catalytic performance toward DEC yield shows a slight decrease after five recycles but still remains at $32.0 \%$, indicating a satisfactory reusability.

\subsection{Studies on structure-property correlation}

Previous studies have shown that both acidity and basicity are important to determine the catalytic activity in ethanolysis of urea. ${ }^{14}$ Herein, to give a deep insight into the relationship between the catalytic performance and acid-base sites of $\mathrm{Mg}_{2}-$ $\mathrm{Zr}_{x} \mathrm{Al}_{1-x}-\mathrm{MMO}$ samples, we correlate the DEC yield with surface acidity and basicity measured by $\mathrm{NH}_{3}-$ and $\mathrm{CO}_{2}$-TPD. As shown in Fig. 6, it's interesting that the DEC yield increases along with the specific surface concentration of medium strength basicity or weak acidity, respectively, demonstrating a synergistic acidbase catalysis for the ethanolysis of urea reaction to synthesize DEC. To further investigate the cooperation mechanism between medium strength basicity and weak acidity and their respective contribution, in situ FTIR of reactants on the catalysts was conducted. The ethanolysis of urea includes two consecutive steps: the formation of intermediate ethyl carbamate (EC) from urea and ethanol, followed by the subsequent conversion to DEC. The second step (reaction of EC with ethanol), is regarded as the rate-limiting step for its unfavorable thermodynamics. ${ }^{2}$ Thus, we carried out the adsorption measurements of urea, EC and DEC over $\mathrm{Mg}_{2} \mathrm{Zr}_{0.53} \mathrm{Al}_{0.47}-\mathrm{MMO}$ and control sample $\left(\mathrm{Mg}_{2} \mathrm{Al}-\mathrm{MMO}\right)$, respectively. Fig. 7A shows the urea adsorption over $\mathrm{Mg}_{2} \mathrm{Zr}_{0.53} \mathrm{Al}_{0.47}-\mathrm{MMO}$ within the temperature range $30-210{ }^{\circ} \mathrm{C}$. At room temperature, the characteristic bands of urea are observed: bands at $3436 \mathrm{~cm}^{-1}$ and $3345 \mathrm{~cm}^{-1}$ are
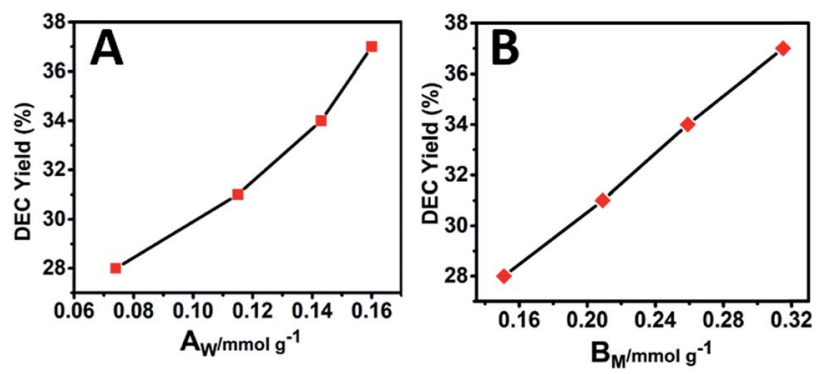

Fig. 6 Correlations between the DEC yield and (A) the surface weak acid site $\left(A_{\mathrm{W}}\right)$ or $(\mathrm{B})$ surface medium strength basic site $\left(B_{\mathrm{M}}\right)$ over $\mathrm{Mg}_{2} \mathrm{Zr}_{x} \mathrm{Al}_{1-x}-\mathrm{MMO}$ samples.

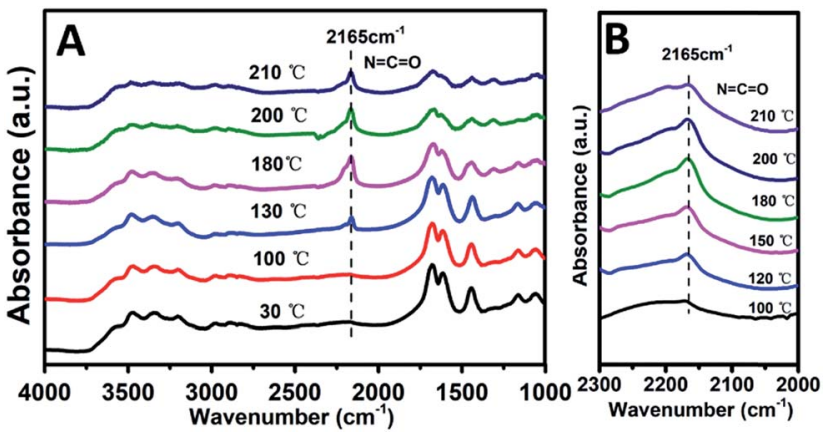

Fig. 7 In situ FTIR spectra of (A) urea and (B) EC over $\mathrm{Mg}_{2} \mathrm{Zr}_{0.53} \mathrm{Al}_{0.47}-$ $\mathrm{MMO}$ sample, respectively, within the temperature range $30-210^{\circ} \mathrm{C}$.

due to $\mathrm{N}-\mathrm{H}$ stretching vibrations; bands at $3213 \mathrm{~cm}^{-1}$ is attributed to the $\mathrm{N}-\mathrm{H}$ stretching vibration with intermolecular association; bands at $1681 \mathrm{~cm}^{-1}$ and $1161 \mathrm{~cm}^{-1}$ are assigned to $\mathrm{C}=\mathrm{O}$ and $\mathrm{C}-\mathrm{N}$ stretching vibrations. A new band at $2165 \mathrm{~cm}^{-1}$ appears at $130{ }^{\circ} \mathrm{C}$ with gradually enhanced intensity until $200{ }^{\circ} \mathrm{C}$, accompanied with decreased bands of urea. This band is assigned to the formation of metal isocyanato group: $\mathrm{O}=\mathrm{C}=\mathrm{N}$ bound to the metal oxide surface $(\mathrm{O}=\mathrm{C}=\mathrm{N}-\mathrm{M}$ asymmetric stretching, $\mathrm{M}$ represent $\left.\mathrm{Al}^{3+}, \mathrm{Zr}^{4+}\right),{ }^{15}$ as a result of the adsorption of urea onto Lewis acid sites $\left(\mathrm{ZrO}_{2}\right.$ and $\mathrm{Al}_{2} \mathrm{O}_{3}$ in $\mathrm{Mg}_{2} \mathrm{Zr}_{0.53} \mathrm{Al}_{0.47}-\mathrm{MMO}$ catalyst).

Furthermore, the adsorption of EC on the catalysts was studied. As shown in Fig. 7B, a band at $2165 \mathrm{~cm}^{-1}$ corresponding to the stretching vibration of $\mathrm{O}=\mathrm{C}=\mathrm{N}$ bound to the metal oxide surface $(\mathrm{O}=\mathrm{C}=\mathrm{N}-\mathrm{M}$ asymmetric stretching, $\mathrm{M}$ represent $\left.\mathrm{Al}^{3+}, \mathrm{Zr}^{4+}\right)$ is observed, whose intensity increases as the temperature rises from 100 to $200{ }^{\circ} \mathrm{C}$, indicating that EC is effectively activated. Compared with EC adsorption on $\mathrm{Mg}_{2} \mathrm{Al}-$ MMO catalyst (Fig. S4: $\dagger \mathrm{O}=\mathrm{C}=\mathrm{N}-\mathrm{M}$ stretching at $2160 \mathrm{~cm}^{-1}$, adsorption temperature at $180{ }^{\circ} \mathrm{C}$ ), a higher frequency of $2165 \mathrm{~cm}^{-1}$ and a lower temperature of $100^{\circ} \mathrm{C}$ are observed for $\mathrm{Mg}_{2} \mathrm{Zr}_{0.53} \mathrm{Al}_{0.47}-\mathrm{MMO}$ catalyst. This lower temperature implies the activation of $\mathrm{EC}$ on $\mathrm{Mg}_{2} \mathrm{Zr}_{0.53} \mathrm{Al}_{0.47}-\mathrm{MMO}$ is more favorable than that on $\mathrm{Mg}_{2} \mathrm{Al}-\mathrm{MMO}$ catalyst. A higher frequency indicates a stronger $\mathrm{O}=\mathrm{C}=\mathrm{N}$ bond but a weaker interaction between $\mathrm{O}$ and acid site in $\mathrm{Mg}_{2} \mathrm{Zr}_{0.53} \mathrm{Al}_{0.47}-\mathrm{MMO}^{2}$ As discussed above, $\mathrm{Mg}_{2} \mathrm{Zr}_{0.53} \mathrm{Al}_{0.47}-\mathrm{MMO}$ catalyst possesses mainly weak acid site deprived from $\mathrm{ZrO}_{2}$ while $\mathrm{Mg}_{2} \mathrm{Al}-\mathrm{MMO}$ offers medium-strong acid site (Fig. $\mathrm{S} 2 \dagger$ ) provided by $\mathrm{Al}_{2} \mathrm{O}_{3}$. In other words, weak Lewis acid site serves as main active site to activate EC over $\mathrm{Mg}_{2} \mathrm{Zr}_{0.53} \mathrm{Al}_{0.47}-\mathrm{MMO}$ while medium-strong Lewis acid site accounts for the activated adsorption of EC over $\mathrm{Mg}_{2} \mathrm{Al}-\mathrm{MMO}$. This is in accordance with the correlation between DEC yield and surface weak acidity measured by $\mathrm{NH}_{3}$-TPD (Fig. 4). The activation of EC by weak Lewis acid site over $\mathrm{Mg}_{2} \mathrm{Zr}_{0.53} \mathrm{Al}_{0.47^{-}}$ MMO catalyst is more efficient than by the medium-strong Lewis acid site over $\mathrm{Mg}_{2} \mathrm{Al}-\mathrm{MMO}$ sample, which promotes the conversion of EC to DEC (the rate-limiting step) with a higher yield of DEC.

Finally, we investigated the adsorption behavior of ethanol over $\mathrm{Mg}_{2} \mathrm{Zr}_{0.53} \mathrm{Al}_{0.47}-\mathrm{MMO}$ at various temperatures (Fig. 8). In the $\mathrm{CH}_{2} / \mathrm{CH}_{3}$ stretching region, two peaks at 2962 and 


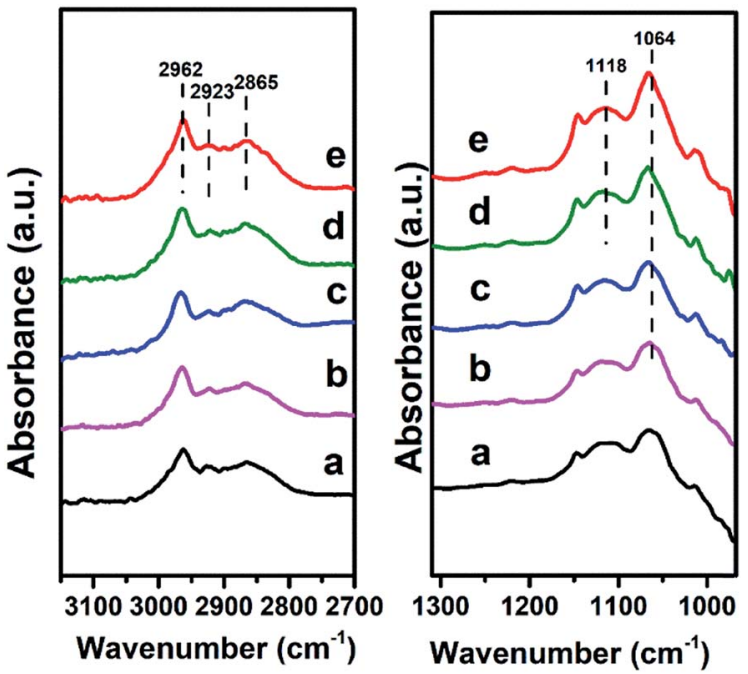

Fig. 8 In situ FTIR spectra evolution of ethanol over $\mathrm{Mg}_{2} \mathrm{Zr}_{0.53} \mathrm{Al}_{0.47}$ MMO at: (a) $100{ }^{\circ} \mathrm{C}$, (b) $120{ }^{\circ} \mathrm{C}$, (c) $150{ }^{\circ} \mathrm{C}$, (d) $180{ }^{\circ} \mathrm{C}$, (e) $200{ }^{\circ} \mathrm{C}$, respectively.

$2923 \mathrm{~cm}^{-1}$ are attributed to $\mathrm{CH}_{3}$ stretching and the peak at $2865 \mathrm{~cm}^{-1}$ is due to $\mathrm{CH}_{2}$ stretching in ethoxide. ${ }^{28}$ In $\mathrm{C}-\mathrm{C}-\mathrm{O}$ stretching regions, the band at $1064 \mathrm{~cm}^{-1}$ and $1118 \mathrm{~cm}^{-1}$ are assigned to adsorbed ethoxide species ${ }^{28}$ over the catalyst, which indicates that ethanol is effectively activated over $\mathrm{Mg}_{2} \mathrm{Zr}_{0.53^{-}}$ $\mathrm{Al}_{0.47}-\mathrm{MMO}$ through the abstraction of $\mathrm{H}^{\delta+}$ by Lewis basic site. Additionally, the peaks intensity of ethoxide species increases gradually when the temperature rises from $100{ }^{\circ} \mathrm{C}$ to $200{ }^{\circ} \mathrm{C}$, indicating an enhanced activation of ethanol over $\mathrm{Mg}_{2} \mathrm{Zr}_{0.53^{-}}$ $\mathrm{Al}_{0.47}-\mathrm{MMO}$ at a higher temperature. In comparison, $\mathrm{Mg}_{2} \mathrm{Al}-$ MMO sample displays two peaks at $1102 \mathrm{~cm}^{-1}$ and $1165 \mathrm{~cm}^{-1}$ (Fig. S5 $\dagger$ ) in $\mathrm{C}-\mathrm{C}-\mathrm{O}$ stretching region, corresponding to the adsorbed ethoxide species. ${ }^{29}$ The large difference in band position suggests that the basic sites provided by the two catalysts are different for the activation of ethanol: $\mathrm{Zr}^{4+}-\mathrm{O}^{2-}$ as main basic site is responsible for the activated adsorption of ethanol (ethoxide species) over $\mathrm{Mg}_{2} \mathrm{Zr}_{0.53} \mathrm{Al}_{0.47}-\mathrm{MMO}$ while $\mathrm{Mg}^{2+}-\mathrm{O}^{2-}$ serves as predominant active center in $\mathrm{Mg}_{2} \mathrm{Al}-\mathrm{MMO}$ sample. Previous study reported that weak basic site can not activate ethanol in this catalytic system. ${ }^{4}$ Thus, based on the combination of in situ FTIR spectra and $\mathrm{CO}_{2}$-TPD results, it is proposed that the presence of medium strength Lewis basic sites $\left(\mathrm{Zr}^{4+}\right.$ $\left.\mathrm{O}^{2-}, \mathrm{Mg}^{2+}-\mathrm{O}^{2-}\right)$ in $\mathrm{Mg}_{2} \mathrm{Zr}_{0.53} \mathrm{Al}_{0.47}-\mathrm{MMO}$ facilitates the activated adsorption of ethanol to produce ethoxide which is involved in the following reaction.

\section{Conclusions}

In summary, acid-base $\mathrm{Mg} / \mathrm{Zr} / \mathrm{Al}$ mixed metal oxides (denoted as $\mathrm{Mg}_{2} \mathrm{Zr}_{x} \mathrm{Al}_{1-x}-\mathrm{MMO}$ ) were successfully synthesized via the calcination transformation of $\mathrm{Mg}_{2} \mathrm{Zr}_{x} \mathrm{Al}_{1-x}-\mathrm{LDH}$ precursors. The obtained $\mathrm{Mg}_{2} \mathrm{Zr}_{x} \mathrm{Al}_{1-x}-\mathrm{MMO}$ catalysts are evaluated by the ethanolysis of urea reaction to produce DEC, and the sample of $\mathrm{Mg}_{2} \mathrm{Zr}_{0.53} \mathrm{Al}_{0.47}-\mathrm{MMO}$ demonstrates the largest DEC yield of $36.7 \%$. Studies on structure-activity correlation reveal a cooperative catalysis between medium strength base site and weak acid site of $\mathrm{Mg}_{2} \mathrm{Zr}_{0.53} \mathrm{Al}_{0.47}-\mathrm{MMO}$ in this reaction. Moreover, $\mathrm{CO}_{2}$ - and $\mathrm{NH}_{3}$-TPD study as well as the in situ FTIR measurements verify that the medium strength Lewis base sites $\left(\mathrm{Zr}^{4+}-\mathrm{O}^{2-}, \mathrm{Mg}^{2+}-\mathrm{O}^{2-}\right)$ serve as active center to activate ethanol to produce ethoxide species; while weak Lewis acid sites (mostly $\mathrm{ZrO}_{2}$ ) act as active site toward EC activation to produce $\mathrm{O}=\mathrm{C}=$ $\mathrm{N}-\mathrm{M}$. Therefore, a synergistic acid-base catalysis is demonstrated in the $\mathrm{Mg}_{2} \mathrm{Zr}_{0.53} \mathrm{Al}_{0.47}-\mathrm{MMO}$ catalyst, accounting for its higher DEC yield toward ethanolysis of urea reaction.

\section{Conflicts of interest}

There are no conflicts to declare.

\section{Acknowledgements}

This work was supported by the National Key Research and Development Program (Grant No. 2017YFA0206804), the National Natural Science Foundation of China (NSFC) and the Fundamental Research Funds for the Central Universities (buctylkxj01).

\section{Notes and references}

1 S. Huang, B. Yan, S. Wang and X. Ma, Chem. Soc. Rev., 2015, 44, 3079-3116.

2 F. Li, H. Li, L. Wang, P. He and Y. Cao, Catal. Sci. Technol., 2015, 5, 1021-1034.

3 K. Shukla and V. C. Srivastava, RSC Adv., 2016, 6, 3262432645.

4 D. Wang, X. Zhang, C. Liu, T. Cheng, W. Wei and Y. Sun, Appl. Catal., A, 2015, 505, 478-486.

5 D. Wang, B. Yang, X. Zhai and L. Zhou, Fuel Process. Technol., 2007, 88, 807-812.

6 I. E. Muskat and F. Strain, US Pat., 2,379,250, 1941.

7 I. Prymak, V. N. Kalevaru, S. Wohlrab and A. Martin, Catal. Sci. Technol., 2015, 5, 2322-2331.

8 J. Wang, Z. Hao and S. Wohlrab, Green Chem., 2017, 19, 3595-3600.

9 I. Zielinska-Nadolska, K. Warmuzinski and J. Richter, Catal. Today, 2006, 114, 226-230.

10 S.-J. Wang, S.-H. Cheng, P.-H. Chiu and K. Huang, Ind. Eng. Chem. Res., 2014, 53, 5982-5995.

11 W. Zhao, W. Peng, D. Wang, N. Zhao, J. Li, F. Xiao, W. Wei and Y. Sun, Catal. Commun., 2009, 10, 655-658.

12 A. Angelini, A. Dibenedetto, D. Curulla-Ferré and M. Aresta, RSC Adv., 2015, 5, 88401-88408.

13 A. Dibenedetto, A. Angelini, M. Aresta, S. Fasciano, M. E. Cucciolito, F. Ruffo, B. M. Aresta, D. Curulla-Ferré and E. De Giglio, Appl. Catal., A, 2015, 493, 1-7.

14 K. Shukla and V. C. Srivastava, Fuel Process. Technol., 2017, 161, 116-124.

15 Y. Gao, W. Peng, N. Zhao, W. Wei and Y. Sun, J. Mol. Catal. A: Chem., 2011, 351, 29-40.

16 Q. Wang and D. O'Hare, Chem. Rev., 2012, 112, 4124-4155. 
17 C. Li, M. Wei, D. G. Evans and X. Duan, Small, 2014, 10, 4469-4486.

18 J. Liu, W. Bing, X. Xue, F. Wang, B. Wang, S. He, Y. Zhang and M. Wei, Catal. Sci. Technol., 2016, 6, 3976-3983.

19 J. Xie, W. Zhuang, W. Zhang, N. Yan, Y. Zhou and J. Wang, ChemCatChem, 2017, 9, 1076-1083.

20 P. Liu, M. Derchi and E. J. M. Hensen, Appl. Catal., A, 2013, 467, 124-131.

21 F. Jiang, L. Zeng, S. Li, G. Liu, S. Wang and J. Gong, ACS Catal., 2014, 5, 438-447.

22 H. Chen, S. He, M. Xu, M. Wei, D. G. Evans and X. Duan, ACS Catal., 2017, 7, 2735-2743.

23 S.-K. Wu, P.-C. Lai, Y.-C. Lin, H.-P. Wan, H.-T. Lee and Y.-H. Chang, ACS Sustainable Chem. Eng., 2013, 1, 349-358.
24 W. Li, X. Nie, X. Jiang, A. Zhang, F. Ding, M. Liu, Z. Liu, X. Guo and C. Song, Appl. Catal., B, 2018, 220, 397-408.

25 J. R. Copeland, I. A. Santillan, S. M. Schimming, J. L. Ewbank and C. Sievers, J. Phys. Chem. C, 2013, 117, 21413-21425.

26 G. S. Foo, D. Wei, D. S. Sholl and C. Sievers, ACS Catal., 2014, 4, 3180-3192.

27 J. Sun, K. Zhu, F. Gao, C. Wang, J. Liu, C. H. Peden and Y. Wang, J. Am. Chem. Soc., 2011, 133, 11096-11099.

28 J. J. Bravo-Suárez, B. Subramaniam and R. V. Chaudhari, Appl. Catal., A, 2013, 455, 234-246.

29 T. W. Birky, J. T. Kozlowski and R. J. Davis, J. Catal., 2013, 298, 130-137. 